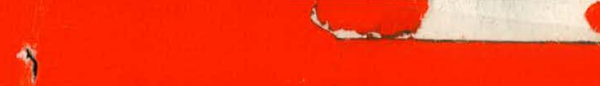

\title{
Advanced Component Research Facility (ACRES)
}

Mark Bohn
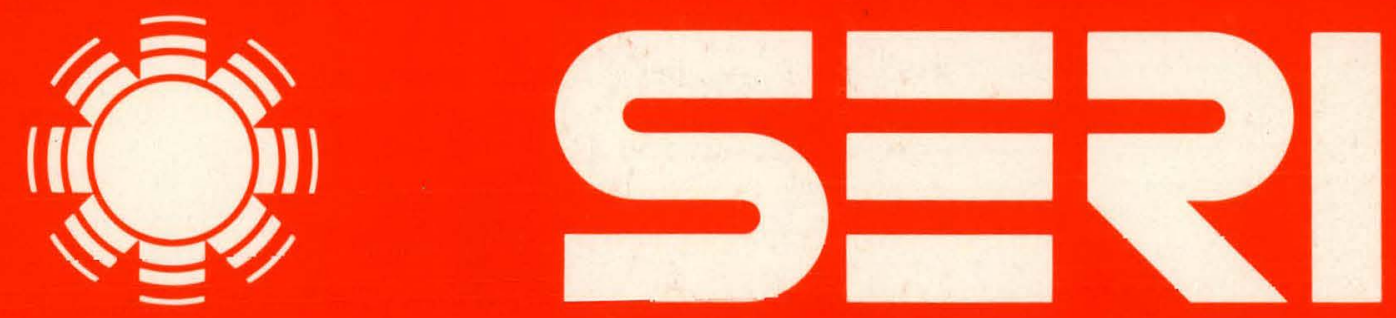

Solar Energy Research Institute

A Division of Midwest Research Institute

1617 Cole Boulevard

Golden, Colorado 80401

Operated for the

U.S. Department of Energy under Contract No. EG-77-C-01-4042 


\section{DISCLAIMER}

This report was prepared as an account of work sponsored by an agency of the United States Government. Neither the United States Government nor any agency Thereof, nor any of their employees, makes any warranty, express or implied, or assumes any legal liability or responsibility for the accuracy, completeness, or usefulness of any information, apparatus, product, or process disclosed, or represents that its use would not infringe privately owned rights. Reference herein to any specific commercial product, process, or service by trade name, trademark, manufacturer, or otherwise does not necessarily constitute or imply its endorsement, recommendation, or favoring by the United States Government or any agency thereof. The views and opinions of authors expressed herein do not necessarily state or reflect those of the United States Government or any agency thereof. 


\section{DISCLAIMER}

Portions of this document may be illegible in electronic image products. Images are produced from the best available original document. 
Printed in the United States of America Available from:

National Technical Information Service

U.S. Department of Commerce

5285 Purl Ruyal Road

Springfield, VA 22161

Price:

\author{
Microfiche $\$ 3.00$ \\ Printed Copy $\$ 4.50$
}

\begin{abstract}
NOTICE
This report was prepared as an account of work sponsored by the United States Government. Neither the United States nor the United States Department of Energy, nor any of their employees, nor any of their contractors, subcontractors, or their employees, makes any warranty, express or implied, or assumes any legal liability or responsibility for the accuracy, completeness or usefulness of any information, apparatus, product or process disclosed, or represents that its use would not infringe privately owned rights.
\end{abstract}


SERI /TR-631-505

UC CATEGORY: UC-62

AOVANCED COMPONENT RESEARCH
FACILITY (ACRES)

MARK BOHN

JULY 1980

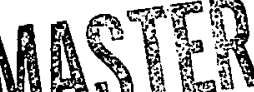

PREPARED UNDER TASK NO. 3457.12

\section{Solar Energy Research Institute}

A Division of Midwest Research Institute

1617 Cole Boulevard

Golden, Colorado 80401

Prepared for the

U.S. Department of Energy

Contract No. EG-77-C-01-4042

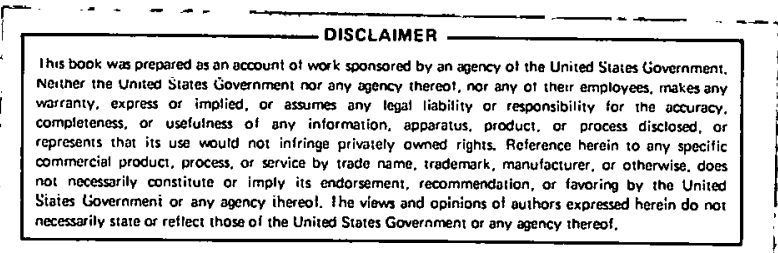


THIS PAGE

WAS INTENTIONALLY

LEFT BLANK 


\section{PREPACE}

This report documents work performed under Task 3431.21-ACRES Facility Development.

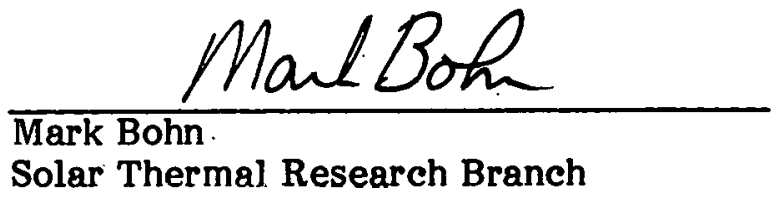

Approved for:

SOLAR ENERGY RESEARCH INSTITUTE

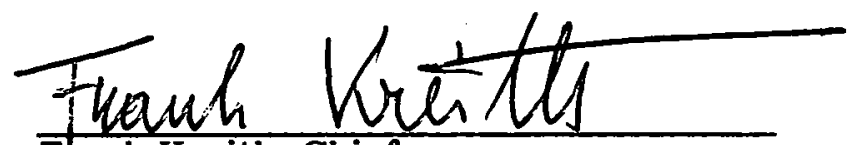

Frank Kreith, Chief

Solar Thermal Research Branch

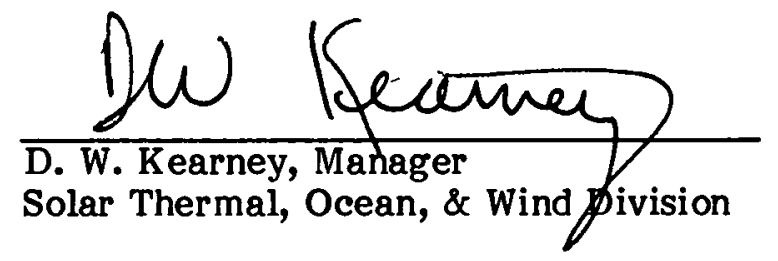




\section{THIS PAGE \\ WAS INTENTIONALLY \\ LEFT BLANK}




\section{SUMMARY}

A detailed description of the SERI Advanced Component Research Facility (ACRES) is given. Background information explicates the history of the facility, which was developed around two Omnium-G parabolic dish concentrators. The Omnium-G concentrators and electrical power plant are described. The purpose and a detailed description of the ACRES facility is given. Included is a description of the measurement capabilities, the controls, and each component of the facility. 


\section{THIS PAGE}

\section{WAS INTENTIONALLY LEFT BLANK}




\section{TABLE OF CONTENTS}

$\underline{\text { Page }}$

1.0 Background....................................

2.0 Omnium-G Equipment $\ldots \ldots \ldots \ldots \ldots \ldots \ldots \ldots \ldots \ldots \ldots \ldots \ldots \ldots \ldots \ldots \ldots$

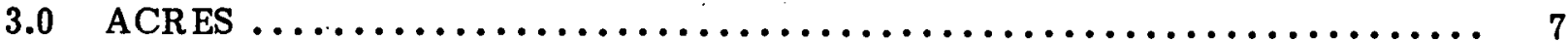

3.1 Introduction $\ldots \ldots \ldots \ldots \ldots \ldots \ldots \ldots \ldots \ldots \ldots \ldots \ldots \ldots \ldots \ldots \ldots \ldots \ldots$

3.2 The Thermal Test Loop ............................ 7

3.3 Controls-Local and Remote ........................... 9

3.4 Primary Instrumentation ............................ 13

3.5 Secondary Instrumentation $\ldots \ldots \ldots \ldots \ldots \ldots \ldots \ldots \ldots \ldots \ldots \ldots \ldots \ldots \ldots \ldots$

3.6 Freeze Protection $\ldots \ldots \ldots \ldots \ldots \ldots \ldots \ldots \ldots \ldots \ldots \ldots \ldots \ldots \ldots \ldots \ldots \ldots$

3.7 Tubing Size................................. 15

$4.0 \quad$ References $\ldots \ldots \ldots \ldots \ldots \ldots \ldots \ldots \ldots \ldots \ldots \ldots \ldots \ldots \ldots \ldots \ldots \ldots \ldots$

Appendix A Description of Each Control Switch by Panel Label ............ A-1

A.1 Flow Control Panel ............................ A-1

A.2 Omnium-G Tracking Controller ................... A-1

A.3 Remote Control Panel .......................... A-2

Appendix B Thermal Test Loop-Component Description ................ B-1 
THIS PAGE

WAS INTENTIONALLY

LEFT BLANK 
SEP

TR -505

LIST OF FIGURES

$\underline{\text { Page }}$

2-1 Omnium-G Parabolic-Dish Concentrator

4

2-2 Omnium-G Electric Power Generating Loop.

5

3-1 ACRES Thermal Test Loop

8

3-2 Photograph of the Omnium-G Tracking Control Panel and the Flow

Control Panel.

10

3-3 Photograph of the Remote Control Panel

11

3-4 ACRES Thermal Test Loop Freeze Protection $\ldots \ldots \ldots \ldots \ldots \ldots \ldots \ldots \ldots$

3-5 Therm al Test Loop -Tubing Size........................ 17

B-1 Electric Preheater

B-2

B-2 Condenser .

B-3

ix 


\section{SECTION 1.0}

\section{BACKGROUND}

The ACRES facility originated as an Omnium-G (OG) Solar Powered Electrical Generating Plant procured by SERI in mid-1978. Because the power plant was commercially available, the Department of Energy directed SERI to purchase, install, test, and report on its performance. The equipment was then to be made available for other research programs at SERI. Interest in high-temperature solar energy applications at SERI was extensive; it appeared that more than one paraboloid concentrator could be fully utilized. Therefore, a second concentrator (without electrical power generating equipment-see Section 2.0) was procured from Omnium-G.

An Omnium-G crew began installation on November 6, 1978. During the installation period, Solar Thermal Conversion Branch personnel procured support as required by the OG purchase agreement (fork-lift, welders, concrete, cranes, etc.) but left the installation completely to OG personnel. At the same time, branch personnel developed an experimental method for measuring the electrical power output of the unit, and design work for the ACRES facility began.

Several problems arose during installation that caused long delays in the completion of the electrical power generating plant. From the nature of these problems, it was clear that the unit was not commercially ready. The power plant was not operational by the end of February 1979, and branch personnel took an alternate approach to determine its performance. At that time, the concentrator and tracking electronics had been installed and adjusted and the receiver was in place. The performance determination was made via a thermal measurement of the concentrator's optical efficiency and the receiver's thermal loss. The technique involved as well as how these measured quantities can be used to determine the deliverable thermal energy of the dish/receiver are described by Bohn (1979a). Thermal and mechanical efficiencies of any end use could be specified and delivered energy was then determined for that end use. A method of determining the temper ature of delivered energy for a wide range of operating conditions is given in Bohn (1979b). Since a wide range of end uses could be found for the concentrator, and since the steam engine/electrical generator was not commercially ready then (nor was it ready as of October 1979) this approach seemed to have much more significance than attempting to measure the electrical output of the OG device.

By June 1, 1979, it appeared that further delays were jeopardizing both the install ation of ACRES and the research programs that depended on it. It was decided by branch personnel that further direct involvement with Omnium-G was not justified, that conversion of the existing equipment to the ACRES facility should begin. Omnium-G corrected some minor problems with the tracking electronics in the north dish, completed installation of the south dish, and turned both dishes over to SERI.

Branch personnel, with support from the Measurement Design and Support Branch (then, Test and Measurements Group), began installation of ACRES.

The purpose of this report is to give a detailed description of the ACRES facility. Sections subsequent to this describe the Omnium-G concentrator and tracking electronics and (for reference) the Omnium-G steam loop/electrical generating equipment. The purpose and design of the ACRES facility are presented, and then a detailed description of the $f a c i l i t y$ is given. 
S=P1部 


\section{SECTION 2.0}

\section{OMNIUM-G EQUIPMENT}

The Omnium-G Solar Powered Electrical Generating Plant is based on a 6-m diameter parabolic-dish concentrator with a nominal focal length of $4 \mathrm{~m}$ (Fig. 2-1). The optical surface is Alzak sheet epoxied on a foam-cast petal. Eighteen of these petals are supported from behind by an aluminum tube support structure. Four tubular aluminum arms are fixed to the support structure and extend to the focal area to provide support for receivers or other experimental packages. The elevation axis is above the reflecting surface, and the elevation drive mechanism and elevation bearing protrude through a $1-\mathrm{m}$ diameter hole in the dish.

Power conversion equipment is located in the circular enclosure below the dish. The axis of this enclosure is also the azimuthal axis of the dish. A bearing surface on top of the enclosure supports the dish on a trolley that provides east-west motion.

One 90-VDC 1/2-HP motor provides elevation drive, and two of these motors are used for the azimuthal drive. Power to the drive motors is controlled by a closed-loop control circuit. An error in tracking angle is detected by a pair of photocells for each axis. The photocell pair is located under a slit, such that when no tracking error exists, the same amount of sunlight falls on the pair. A tracking error causes more light to fall on one of the cells, and the output of the two cells is then biased. This bias signal is amplified by a voltage comparator, followed by several stages of power amplification, and then it drives the DC motors. There are two adjustments to the circuit. A gain adjustment at the input makes it possible to change the threshold of the tracking error that produces motor drive signal. Note that an error signal greater than this threshold causes full power to be applied to the motor. The second adjustment is the voltage applied to the motors, which can be set to 12 or 24 VDC. Under high-wind conditions, the higher voltage is sometimes required to track.

A diagram of the power conversion equipment is shown in Fig. 2-2. The feedpump provides high-pressure, preheated water to the receiver, which is located at the dish focus. A check valve and bypass regulator control feedwater pressure and prevent backflow. Steam, which is generated in the receiver, is returned to the enclosure and expanded in a two-cylinder steam engine; it is then condensed and returned to the feedwater reservoir. Energy from the condenser is rejected to a 600-gallon insulated vessel-the hot well-which can then be used as a source of low-temperature heat.

The steam engine, electrical generator, and a 2-HP DC motor are mechanically coupled in such a way that three-phase AC load, available steam flow, and stored electrical energy (in the 240-VDC storage battery) are balanced. For example, if no AC load is required, but steam is available, it can be used to charge the storage battery. If an AC load is then required, the battery can be used to supply any power beyond the steam flow capacity or to absorb any excess-thereby improving response to varying AC loads. Primary inputs to the circuit that controls the loads are generator frequency and sustainer motor armature current (direction and magnitude). Primary outputs are the feedpump speed and sustainer motor field current.

Although this load control circuit provides a good solution to the problem of slow response in the thermal energy loop, it creates special problems when one wishes to determine the electrical power generating capability of the unit. The method developed by 

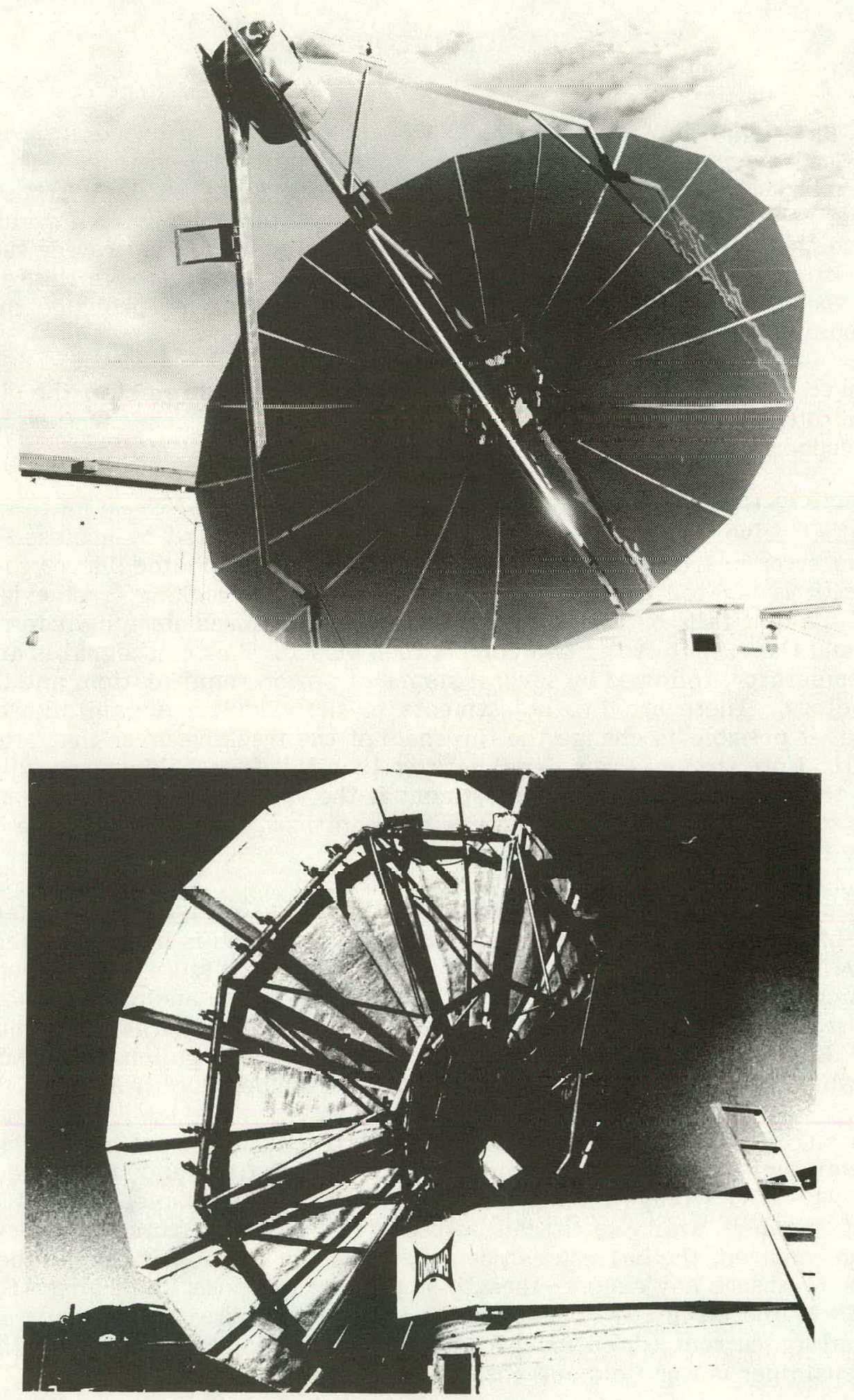

Figure 2-1. Omnium-G Parabolic-Dish Concentrator 


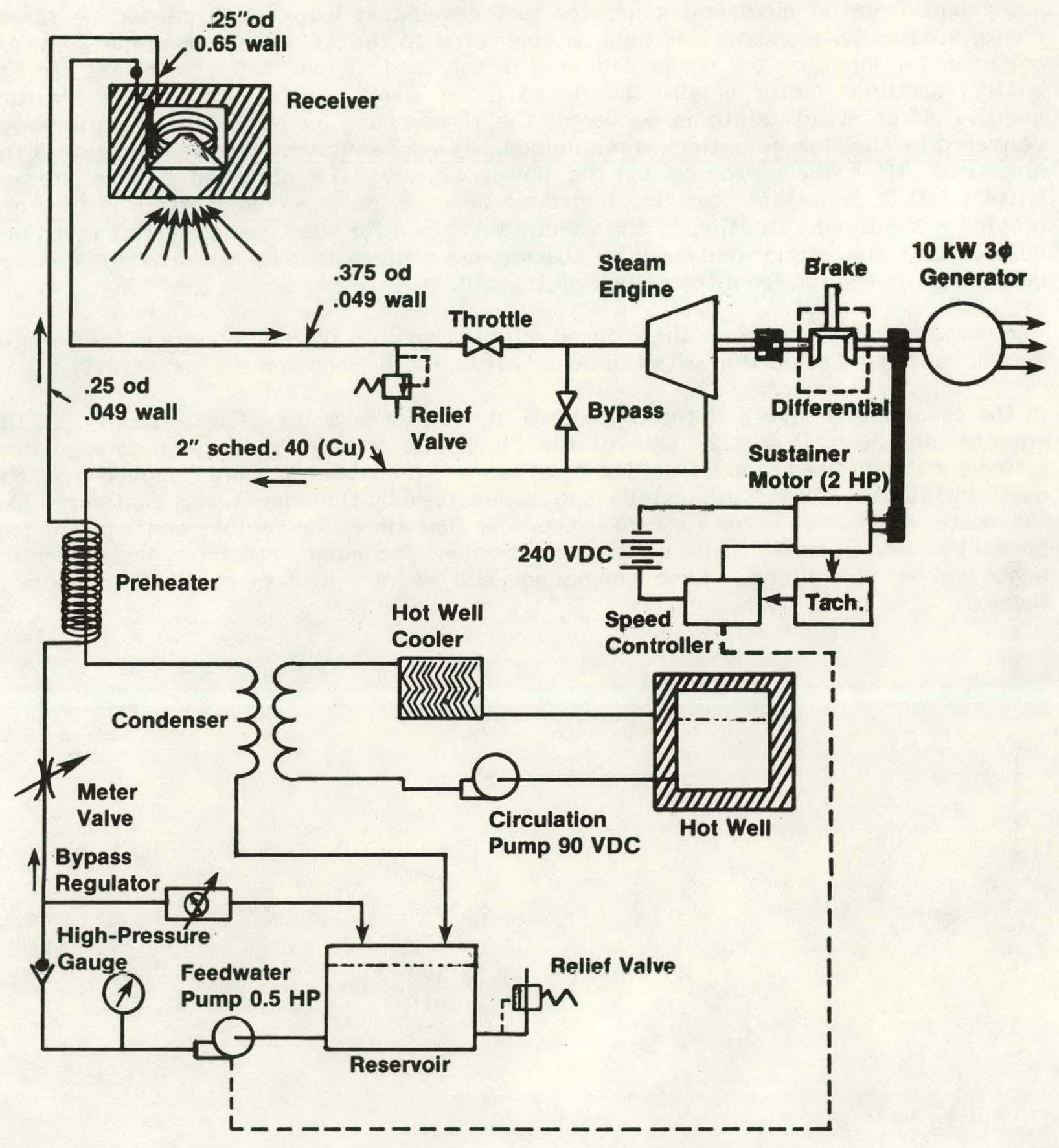

Figure 2-2. Omnium-G Electric Power Generating Loop 
branch personnel (but not actually used; see Section 1.0 regarding conversion of equipment from an electrical generator to thermal test loop) is as follows. A threephase, adjustable, resistive-load bank is connected to the $\mathrm{AC}$ generator output. An AC power meter monitors the power delivered to this load. Power delivered by the storage battery/sustainer motor is also monitored (by a shunt resistor and voltage measurement). After steady state is achieved, the three-phase load is adjusted until power delivered by the storage battery is minimized. Power delivery by the steam engine is the measured AC load, corrected by the power delivered or absorbed by the storage battery. It is important that this technique be used, because the storage battery can provide a significant fraction of the required $\mathrm{AC}$ load for short periods. This technique ensures that the energy delivered by the storage battery is small and that this energy delivery is subtracted from the delivered AC load.

The receiver, which converts the focused solar energy into thermal energy in the form of steam, has been discussed in detail in Bohn (1979a,b) and Webb and Pohlman (1979).

In the process of converting the Omnium-G installation into the ACRES facility, all the components shown in Fig. 2-1 except the feedpump, pressure gauge, bypass regulator, water and steam lines to and from the receiver, and the reservoir were removed from the north installation. The south installation, as delivered by Omnium-G, was configured like the north installation after its conversion. At that time, the facility consisted of two concentrators, tracking hardware and electronics, feedpump, reservoir, and miscellaneous valves and piping. Each component will be discussed in detail in subsequent sections. 


\section{SECTION 3.0}

\section{ACRES}

\subsection{INTRODUCTION}

The purpose of the ACRES facility is to allow SERI to research components related to point-focus collectors. The components of interest include receivers, optics, tracking controls, and energy-transport methods. For example, ACRES will be used in late FY 80 to test a cavity receiver developed by branch personnel. This receiver is expected to operate at temperatures up to $1700^{\circ} \mathrm{F}$ and it will be the basis of a thermochemical receiver for various processes under consideration in SERI laboratories.

Component testing of this type can be classified as either thermal testing or optical testing. In the former, focused energy is measured in terms of a temperature increase or phase change in a working fluid or material due to absorption of optical energy. In the latter, focused optical energy is measured directly by some means. In some ways, thermal testing is simpler, and for many components it is the most direct route. For example, testing of a thermal receiver will typically call for pumping a fluid coolant through the receiver. Measurement of coolant flow rate and the change of fluid state point across the receiver give the energy delivered to the coolant by the receiver. Of interest here may be the energy delivery (normalized by the beam insolation $\mathrm{x}$ dish aperture area) as a function of receiver temperature or fluid outlet temperature. Since losses increase with operating temperatures, this type of efficiency measurement is necessary for hightemperature receivers.

Optical techniques, on the other hand, measure focused optical energy. This may be a more-direct method for evaluating reflecting surfaces or tracking controls. For example, a measurement of flux intensity, near the focal zone of the dish, may be of interest.

Initial design concepts for ACRES were based on the ability to test thermally and optically. As the facility exists now, the north dish has been configured as a very flexible thermal test loop; the south dish will be used initially for optical testing, and during FY80 it will become a duplicate of the north dish thermal test loop.

\subsection{THE THERMAL TEST LOOP}

The north dish thermal test loop (Fig. 3-1) was designed around a water coolant system similar to the original Omnium-G equipment. The major difference is that the thermal test loop provides a great deal more flexibility in controlling operating points. Feedwater taken from the reservoir is pumped to pressure (up to about $10,000 \mathrm{kPa}$ ). The bypass regulator sets the maximum pressure in the loop. High-pressure water passes through the electrical preheater, pressure and temperatures are measured at this point, and the water exits the enclosure and flows up to the focus, where pressure and temperature may be measured twice (receiver inlet and outlet, for example). After reentering the enclosure, pressure and temperature are measured again. Heat is rejected from the feedwater as it passes through the water-cooled condenser, and it then flows through the throttle/throttle bypass, which sets feedwater pressure. A bypassable turbine meter measures feedwater flow rate before the water returns to the reservoir. 


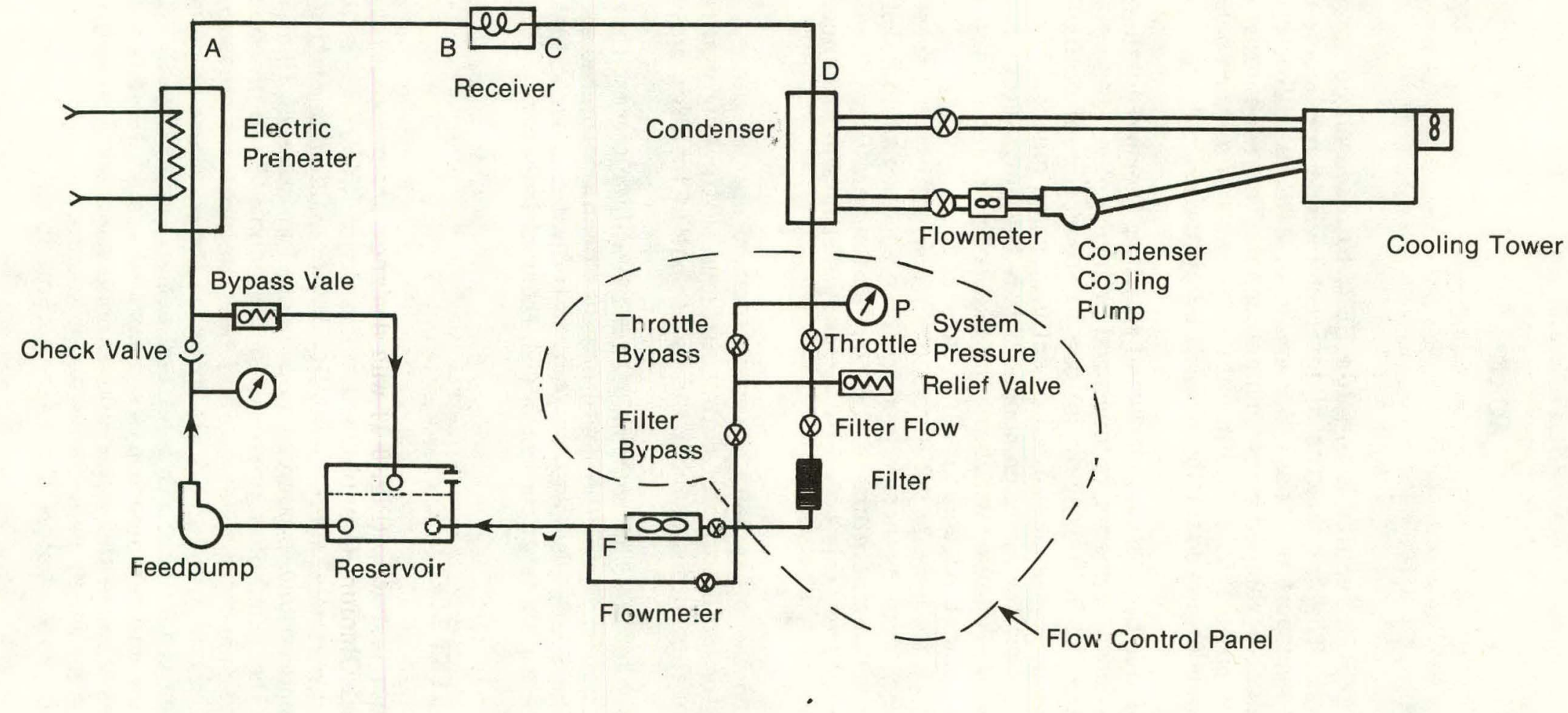

Figure 3-1. ACRES Thermal Test Loop 
Details of thermal test loop components are given in Appendix B. These components include: feedpump, preheaters, measurement sections, condenser, throttle/throttle bypass, and filter/filter bypass.

Flexibility is provided by the independent nature of the loop controls (discussed in detail in the next section). Prim ary test variables-flow rate, pressure, and receiver temperature-are fully adjustable. Feedwater flow rate is determined by the pump speed, since it is a positive displacement pump. Loop pressure may then be set by adjusting the throttle and/or throttle bypass. Receiver inlet temperature, and therefore receiver operating temperature, may be set by setting the preheater outlet temperature. Thus, a given receiver could be tested over a wide range of operating temperatures, flow rates, and pressures. Absorbed energy can be determined from feedwater pressure and temperature changes in the loop, and the energy is then rejected to the cooling tower. Energy transport methods can be studied by measurements of pressure and temperature changes as the fluid travels from the enclosure to the focus and returns to the enclosure. Optical measurements can be made indirectly calorimetrically, for example, as can performance of tracking controls.

\subsection{CONTROLS-LOCAL AND REMOTE}

For safety purposes, many loop controls have been "remoted" and may be operated from the control room as well as from in the enclosure. Figure 3-2 is a photograph of the control panel in the enclosure and Fig. 3-3 is a photograph of the control panel in the control room. For reference, all control switches are listed in Appendix A as they appear on the control panels. The function of each control is described.

Controls seen in the lower half of Fig. 3-2 (flow control panel) are shown functionally in Fig. 3-1. In the top half of Fig. 3-2, the tracking electronics supplied by Omnium-G is shown. The pressure gauge seen in Fig. 3-2 gives loop pressure-specifically, that downstream of the condenser. This pressure is set by the feedpump speed and the throttle/throttle bypass valves. The feedpump speed control is on the top right corner of the flow control panel. The throttle is actuated by a 4-20 mA signal and may be opened or closed by the ten-turn potentiometer located just to the right of the pressure gauge (Fig. 3-2). For high-pressure operation, the large throttle bypass (located just below the throttle potentiometer) is manually closed; for maximum flow rate, it is fully opened. The toggle switch, located above the throttle bypass, turns on the condenser cooling pump and circulates water from the cooling tower to the condenser cooling jacket. The cooling tower fan must be turned on manually by a switch located on the east side of the cooling tower.

In norm al operation, the filter bypass valve, located below the throttle bypass (Fig. 3-2) is fully open and the filter flow toggle switch is in the off-position. If the loop is opened for plumbing or equipment changes, or if the feedwater is changed, it may be desirable to filter the flow before operating at high temperature or before using the turbine flow meter. The filter bypass can be closed and the filter toggle switch to the on-position. Flow is then diverted through a 250 -micron filter (filter cartridges are interchangeable). This process should be carried out at low flow rates, due to a large pressure drop across the filter. If the filter is obstructed, or if both filter valves are inadvertently closed, a relief valve opens at about $150 \mathrm{psi}$. This relief valve is located behind the flow control panel (right side) and also protects the turbine flow meter and solenoid valves should a blockage occur at the reservoir inlet. 

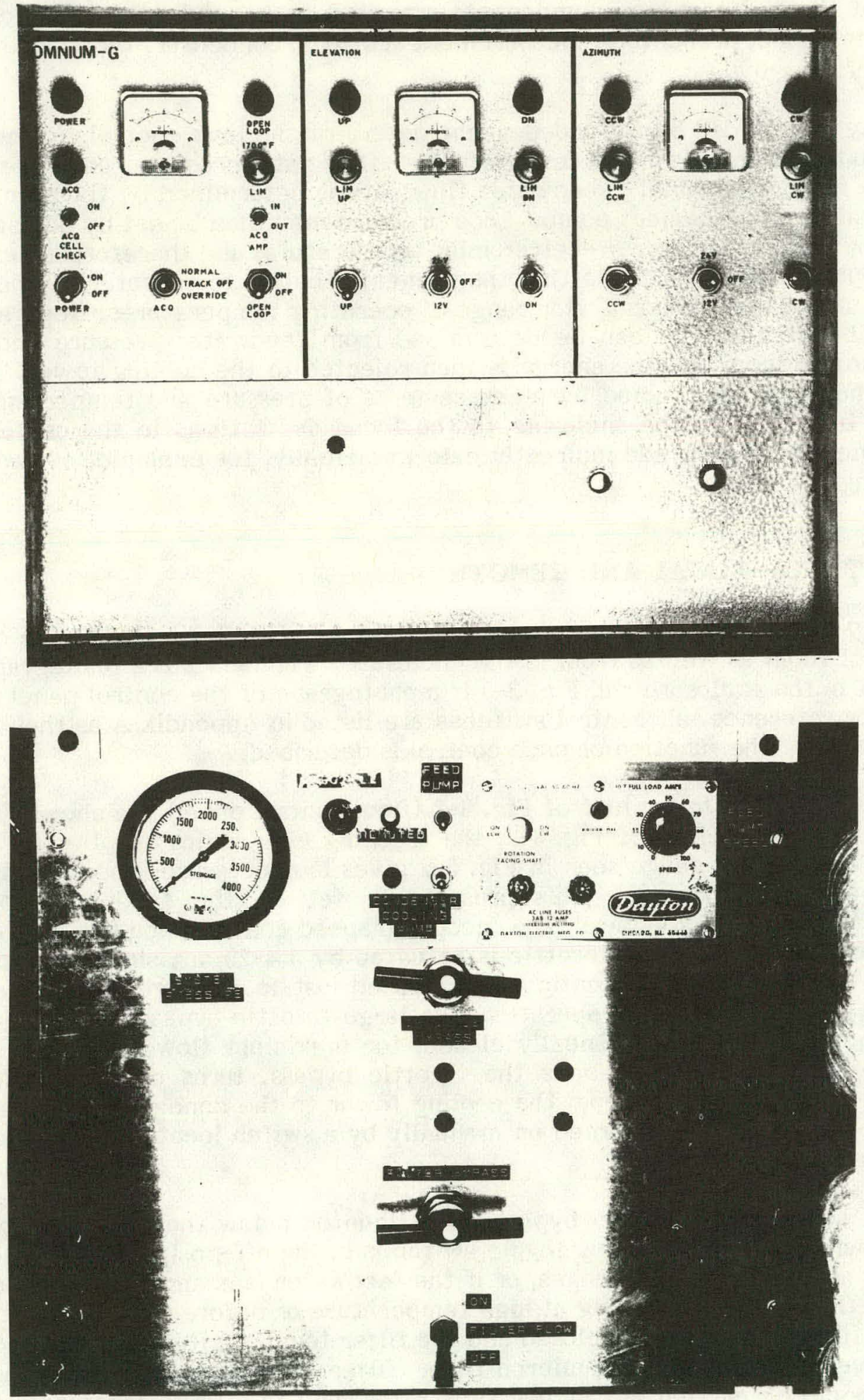

Figure 3-2. Omnium-G Tracking Electronics and Flow Control Panel 
NORTH DISH

6

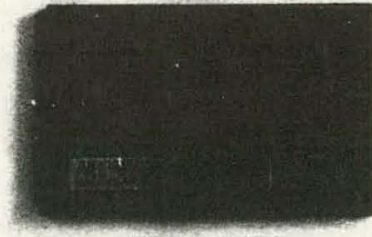

FLOW RATE

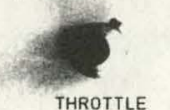

C)

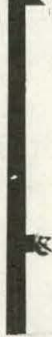

$\underbrace{}_{\text {reto pum }}$

(i) Pे P

COOLING

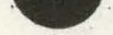

FEED PUMP

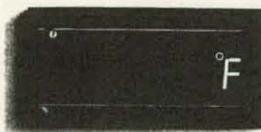

RECEIVER TEMP

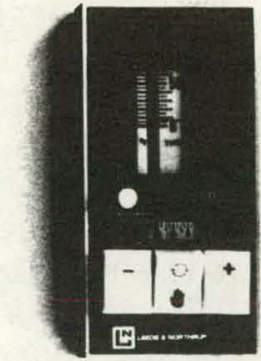

PREHFATER
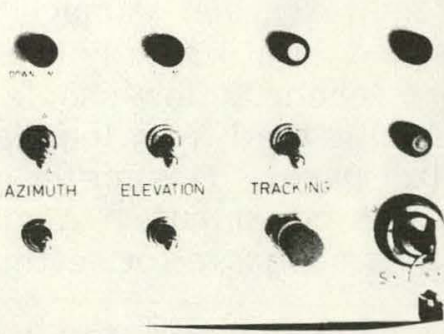

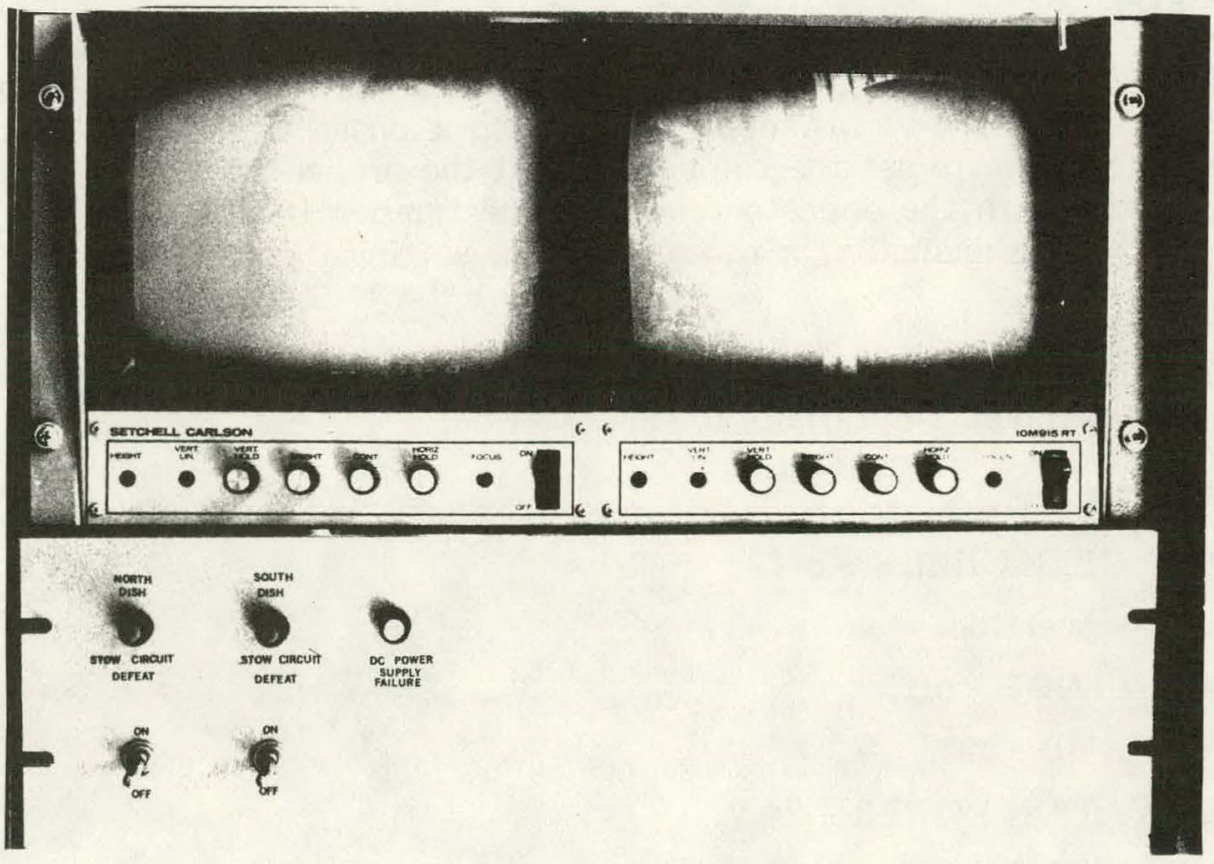

Figure 3-3. Remote Control Panel

Video Monitors 
Controls shown in Fig. 3-2, which are required for high-temperature operation, have been remoted to the control building for safety purposes. The remote control panel, shown in Fig. 3-3, is actuated by turning the key switch (lower right corner) to the on-position. The yellow lamp, labeled REMOTED on the flow control panel, lights to indicate that control has been transferred to the remote control panel in the control room. Then, the inoperative controls on the flow control panel are: throttle, feedpump on/off and speed, and condenser cooling pump.

The feedpump on/off and speed control, the throttle, and the condenser cooling pump are clearly labeled on the remote control panel (as shown in Fig. 3-3). The toggle switch, labeled FLOWMETER, allows all the feedwater flow to be bypassed around the turbine meter, or-in the INLINE position-allows all the feedwater flow to pass through the turbine meter. This is necessary, due to the fragile nature of the turbine meter. Contamination in the feedwater can damage the turbine bearings, and steam can cause the turbine to overspeed. Until steady conditions with clean fecdwater and completely condensed steam are reached, flow should he bypassed around the turbine meter. Approximate flow rate can be read from the digital panel meter, located in the top left corner of the remote control panel. This meter gives a readout of the feedpump shaft speed and is calibrated in gallons per minute. Accuracy is better than $\pm 1 / 2 \%$ above $1 \mathrm{gpm}$, and $\pm 2 \%$ at $0.1 \mathrm{gpm}$, which is adequate for setting the operating point.

The panel meter labeled RECEIVER TEMP in Fig. 3-3 is intended to be connected to a type-K (Chromel-Alumel) thermocouple, which reads the highest temperature in an experiment. For example, the thermocouple may be used to sense the temperature in the thermal mass of a receiver. The meter has an alarm ouput that forces the dish to stow (optical axis vertical) in the event a temperature above a preset level (currently set to $1100^{\circ} \mathrm{F}$ ) occurs. The readout is also useful as a visual indication of the highest temperature in the loop.

Control of the electric preheater is provided by a Leeds \& Northrup Centry controller. The controller sends a 4-20 mA control signal to a phase-triggered SCR power supply. This device allows one to set the temperature at the prcheatcr outlet. Oprer'ilion can be either automatic, with the operator choosing the temperature and the controller acting like a thermostat, or manually, with the operator setting the fraction of full-power input desired.

Omnium-G tracking controls are shown in the upper half of Fig. 3-2. For local or remote control, switches should be in the following position:

1. POWER - on,

2. ACQ CELL CHECK - off,

3. $\mathrm{ACQ}$ - override,

4. OPEN LOOP - off,

5. ACQ AMP - out,

6. ELEVATION POWER - $24 \mathrm{~V}$,

7. AZIIMU'I'H POWER - $12 \mathrm{~V}$ (24 V in high wind).

The dish may be slewed by pressing the momentary toggle switches UP, DOWN, CW, or $\mathrm{CCW}$ until the sun is acquired. Tracking error is read on the meters located in the elevation section and the azimuth section of the tracking control. The meters are not 
functional during slewing. Acquisition of the sun is accomplished by slewing the dish in the close vicinity of the sun and by noting meter readings after the slew switches are released. If the sun has been acquired, the meter readings will move to zero and the UP, or DOWN, and/or $\mathrm{CW}$ or $\mathrm{CCW}$ lamp will indicate that the tracking motors are receiving power to drive the dish. If the sun has not been acquired, the result will be either automatic slewing in a random direction, or no response at all. In the latter case, damage could occur to parts of the receiver support beam near the focus, due to overheating.

Remote tracking is accomplished from the remote control panel (Fig. 3-3). Switches on the Omnium-G tracking controller should be as indicated by the above list. The key switch in the remote control panel should be in the ON position. When the TRACKING switch is in the AUTO position, full control is given to the Omnium-G tracking controller. In the MANUAL position, control is taken away from the Omnium-G controller, and the switches labeled AZIMUTH or ELEVATION can then apply 12 or $24 \mathrm{~V}$ (FAST or SLOW position) directly to the tracking motors, through the limit switches. The television monitor shown in Fig. 3-3 is used in remote acquisition.

Remote acquisition is accomplished by slewing the dish until it is in the general direction of the sun. A television camera is focused on the concentrator focal plane and can be used to help slew the sun into the focus by observing the video monitor located below the remote control panel. Tracking control can then be returned to the Omnium-G controller by switching the TRACKING control to AUTO. If the tracking is functioning properly, forcing the dish out of focus slightly should result in a corrective action by the controller, tending to restore focus. To do this, switch to manual tracking, slew the dish until the sun's image moves about half way across the video monitor, then return to auto tracking. The solar image in the monitor should move back to the center of the monitor.

On the front of the Omnium-G tracking controller shown in Fig. 3-3, three small silver buttons are visible on the lower half of the controller. The two buttons on the right side cover small potentiometers within the controller circuitry. These potentiometers control the gain of the photocell discriminator circuit and must be adjusted for each channel. Clockwise rotation of the potentiometers increases the gain and can cause dish oscillation. Counterclockwise rotation decreases the gain and can cause the tracking to stop. The required adjustment for these potentiometers depends on sky condition, wind, tracking control power supply (batteries), dish counterbalancing, and tracking-motor voltage setting. Correct adjustment is the highest gain that will not cause sustained oscillation.

\subsection{PRIMARY INSTRUMENTATION}

Five measurement sections throughout the thermal test loop provide primary measurement capability. Complete details are given in Measurements Incorporated (1979), which is documentation provided by the manufacturer of the measurement sections. These sections are denoted $\mathrm{A}, \mathrm{B}, \mathrm{C}, \mathrm{D}$, and F, in Fig. 3-1. Measurement section $\mathrm{A}$ is downstream of the preheater, just upstream of the point where the fluid exits the enclosure. Measurement section $D$ is upstream of the condenser, just downstream of the point where the fluid enters the enclosure from the focal area. Measurement sections B and C are located near the focal area. Measurement section $F$ is the turbine flow meter and bypass valves. Sections A, B, C, and D measure feedwater (or steam) temperature and pressure, thus giving the state of the fluid at four locations. From these measurements and the output of the turbine flow meter, it is possible to determine: 
1. Rate of enthalpy rise across the receiver;

2. Pressure loss across the receiver;

3. Enthalpy loss as a result of pumping the feedwater to the focal area from the enclosure;

4. Pressure loss resulting from pumping the feedwater to focal area;

5. Enthalpy loss as a result of steam passage from the focal area to the enclosure;

6. Pressure loss as a result of steam passage from the focal area to the enclosure; and

7. Net rate at which energy is added to the working fluid by the concentrator/ receiver.

The various combinations of measurements can give information on receiver performance, transport losses, concentrator optical quality, and performance of the combination of all three, i.e., a complete concentrator/receiver/energy delivery system. Thus, thermal energy delivered to any end use can be determined.

Details of the five measurement sections are given in the reference, but a brief description follows. Sections A, B, C, and D consist of a rectangular block of 316 stainless steel with flow passages and probe receptacles drilled in place. Probe passages include one pressure tap and two temperature probe holes. An oil-filled capillary tube transmits the pressure signal to a piezoelectric pressure transducer. One temperature probe hole is used for calibration purposes; the other houses a thermocouple or RTD, depending on desired operating temperature. To prevent overheating of the pressure transducer, a small water-cooled heat exchanger cools the capillary tube just before it enters the transducer. Also, at this point, a thermocouple probe reads the temperature of the transducer fitting to ensure that it is properly cooled. These precautions were taken because these four transducers are very long lead items, and damage due to overheating could result in long delays.

'I'he flowmeter, as previously mentioned, is a turblne-type transdurer wlll, extended-range capability and bypass solenoid valves. The extended range allows the same turbine meter to be used for very low flow rates (high-temperature testing) and high flow rates (low-temperature testing).

Maximum measurement flexibility has been provided by the use of an insulated, shielded, 60 -terminal isothermal block near the focal area. This allows up to 20 isolated, shielded, voltage or temperature measurements of any type to be accommodated in an experimental package at the focal area. A similar isothermal block, with 120 terminals, Is located in the enclosure.

Beam insolation is measured with an Eppley normal incidence pyrheliometer (NIP). The NIP is fixed to the frame of the north dish and tracks the sun anytime the dish is tracking. Generally, all thermal measurements are scaled to a beam insolation of $1000 \mathrm{~W} / \mathrm{m}^{2}$.

\subsection{SECONDARY INSTRUMENTATION}

Several temperature measurements are provided through the loop for the purpose of loop control or backup measurements. 
Preheater outlet temperature is provided by a thermocouple (type $\mathrm{J}$ ) embedded in the preheater. This thermocouple provides the control signal to the preheater controller located on the remote control panel.

The four primary instrumentation pressure transducers have type- $T$ thermocouples inserted in their fittings. These thermocouples determine if the pressure transducers are overheating.

A pair of type-T thermocouples inserted in the condenser cooling shell (Fig. 3-1) provides temperature rise across the cooling side of the condenser. A target flowmeter in the cooling line gives cooling flow rate. These three measurements may be used to calorimetrically determine energy exchange rates in the loop.

A type-T thermocouple is inserted in the feedwater line at the condenser outlet. This measurement, in conjunction with the pressure measured at section $\mathrm{D}$, can be used to check the state of the fluid exiting the condenser. In this way, condenser performance can be monitored. For example, if steam is generated in the receiver, it should be fully condensed before passing through the throttle or the turbine flowmeter. If a gas is used as the receiver coolant, it may be desirable to measure flow. rate af ter the condenser. In this case, adequate cooling of the gas by the condenser must be ensured so as to protect the flow measurement device.

\subsection{FREEZE PROTECTION}

Since ACRES is an outdoor facility, considerable effort went into ensuring that freezing temperatures would not damage the thermal test loop. Figure 3-4 shows details of the test loop that involve insulation, heat tracing, or immersion heaters. Power required to operate the tracing and heaters is taken from utility power, ensuring constant protection.

Heat for the main loop is provided by two immersion heaters (GE Calrod MP 1301) with thermostatic control in the feedwater reservoir. Each heater is rated at $300 \mathrm{~W}$, 110 VAC. (In the event the reservoir is drained, the heaters should be disconnected or the thermostat set to a low temperature.) The feedpump is then run at low speed to circulate warm water from the reservoir through the test loop. The test loop is insulated, but if an uninsulated test package is plumbed into the focal area, it will be necessary to insulate during down time. Otherwise, losses may exceed the $600 \mathrm{~W}$ that are provided by the reservoir immersion heaters.

The cooling tower is protected by a $2-\mathrm{kW}$ basin heater, thermostatically controlled and powered through a basin float switch.

Piping from the tower to the condenser is heat traced and insulated with one-inch pipe insulation, and aluminum cover protects the insulation on piping exterior to the enclostre.

\subsection{TUBNG SIZE}

Tubing in the thermal test loop is 316 stainless steel. In Figure 3-5 the size of the tubing is shown. This includes tubing inside diameter, wall thickness, and length of various sections of tubing that comprise the loop. This information is useful for calculating pressure drop or tubing limitations. 


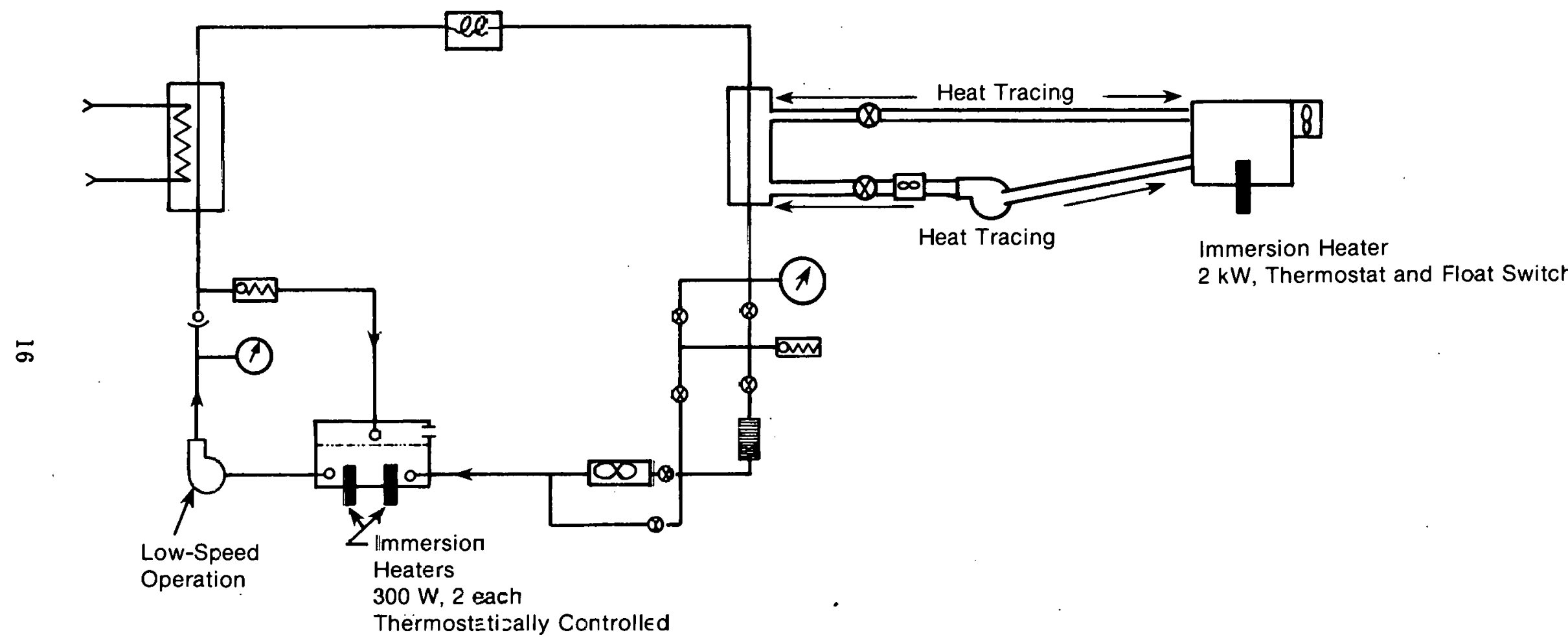

Figure 3-4. ACRES Thermal Test Loop Freeze Protection 


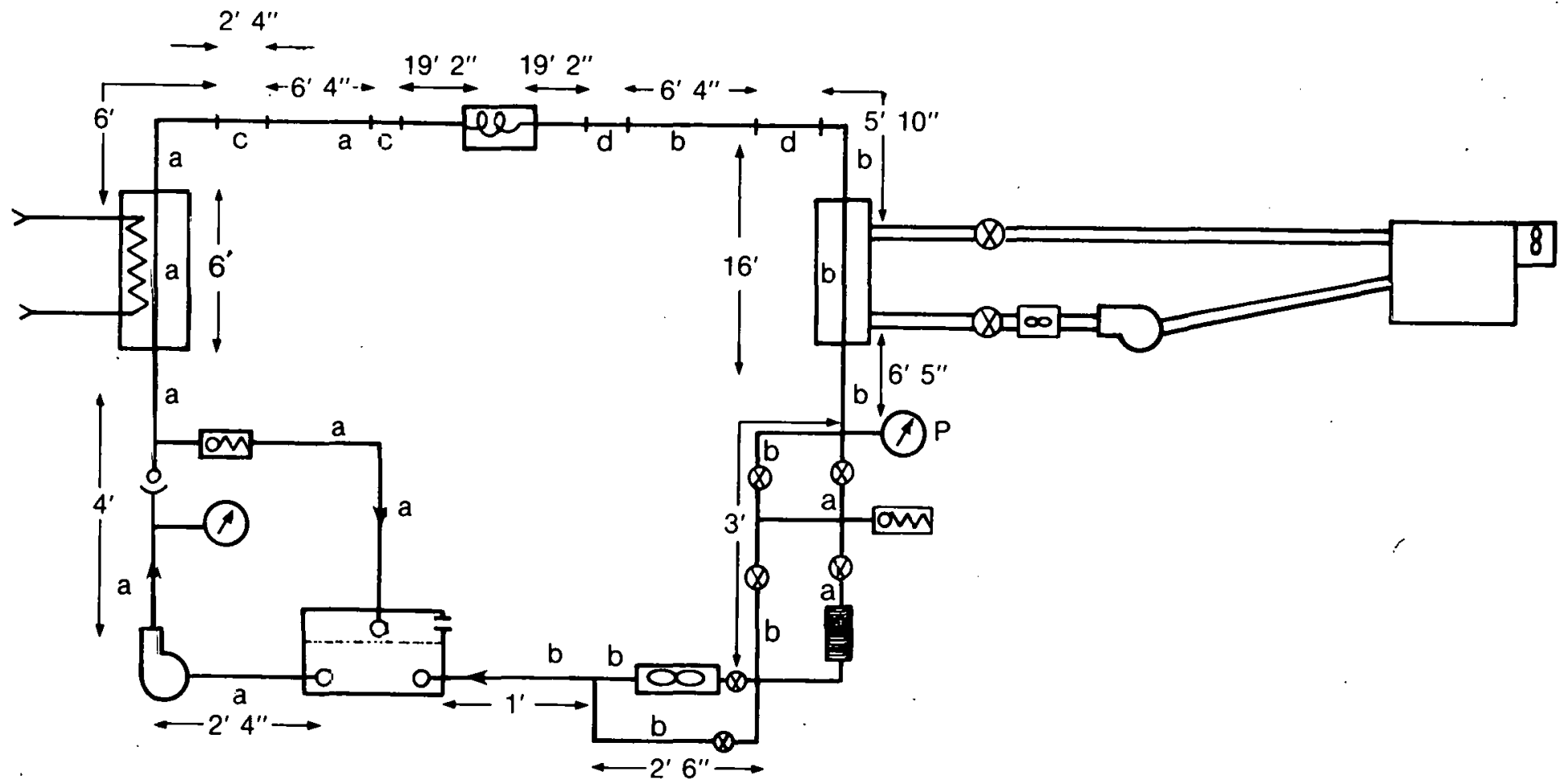

$a=1 / 4^{\prime \prime}, 0.049^{\prime \prime}$ wal

$\mathrm{b}=3 / 8^{\prime \prime}, 0.049^{\prime \prime} \mathrm{wal}$

$c=1 / 4 "$ SAE 100R2 Type A Flex Hose, 2' 4" long

$\mathrm{d}=$ Swagelock Braided Flex Hose, 3' long

Figure 3-5. ACRES Thermal Test Loop Tubing Size 


\section{SEP잉}




\section{SECTION 4.0}

\section{REFERENCES}

Bohn, M. S. 1979a. Performance Characteristics of a Commercially Available PointFocus Solar Power System. SERI/TP-34-169. Golden, CO: Solar Energy Research Institute. (Also in Proceedings; ASME/AIChE Heat Transfer Conference; August 1979).

Bohn, M. S. 1979b. Analysis of the Omnium-G Receiver. SERI/TR-34-387. Golden, CO: Solar Energy Research Institute.

Measurements Incorporated. 1979. Instructions and Calibration Data for Instrumental Measurment Sections, Prepared for Solar Energy Research Institute. AK-9-0557-I. Idaho Falls, Idaho.

Webb, J. D.; Pohlm an, S. L. 1979. Reli ability and Durability of a Therm al Receiver Utilizing ASI Type 315 Stainless Steel in Contact with Molten Aluminum. SERI/TR-31338. Golden, CO: Solar Energy Rese arch Institute. 
SEPI 


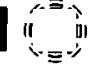

\section{APPENDIX A}

DESCRIPTION OF RACH CONTROL SWTTCH BY PANEL LABEL

\section{A.1 PLOW CONTROL PANEL (See Figs. 3-1 and 3-2)}

SYSTEM PRESSURE

THROTTLE

THROTTLE BYPASS

FEEDPUMP

FEEDPUMP SPEED

CONDENSER COOLING

PUMP

FILTER FLOW

FILTER BYPASS
Reads feedwater pressure (in psi) downstream of condenser.

A ten-turn potentiometer that controls a ten-turn metering valve. This valve is used to set system pressure. Clockwise rotation closes the valve.

A low-restriction valve used to minimize pressure drop in the loop by bypassing flow around the throttle. For high-pressure operation, this valve can be closed.

An electrical switch that turns on the feedpump motor.

A potentiometer that controls feedpump speed.

An electrical toggle switch that turns on a pump and circulates cooling water through the cooling tower and condenser cooling jacket.

A toggle valve that, in the off position, prevents flow through a 250-micron filter.

A low-restriction valve that bypasses flow around the filter and filter flow switch.

\section{A.2 OMNIUM-G TRACKING CONTROL (Fig. 3-2)}

POWER

$A C Q$

OPEN LOOP
Applies power (24 V) to the electronic circuitry.

Controls tracking mode. In the overide mode, the controller will always attempt to track. In the normal mode, a loss of acquisition indicated by the acquisition cell circuit will stop tracking. In the off-position, no tracking will occur.

Refers to the ephemeral tracker (not operative in the SERI system). During normal mode tracking, a loss of sun acquisition will cause the controller to change to open loop tracking via an ephemeral (clock) tracker. With this switch on, the ephemeral tracking is on full time. 
ACQ AMP

ELEVATION (meter)

DOWN, UP (lamps)

$24 \mathrm{~V}, \mathrm{OFF}, 12 \mathrm{~V}$

UP, DOWN (toggle)

AZIMUTH (meter)

CW, CCW (lamps)

$24 \mathrm{~V}, \mathrm{OFF}, 12 \mathrm{~V}$

rW, CCW, (toggle)
Amplifies the signal from the acquisition cell so that acquisition under low light conditions (moonlight, for example) can be achieved.

A reading right of zero indicates a positive elevation error-the optical axis above the sun.

Indicates that power is being applied to the elevation drive motor.

Controls voltage level applied to elevation drive motor. In the off position, the motor cannot be driven by any means.

Momentary switches that apply power $(0,12$, or $24 \mathrm{~V})$ to the elevaliun inutur for slewing the dish.

A reading right of zero indicates a positive azimuth error-optical axis is counterclockwise of the sun.

Indicates that power is being applied to the azimuth drive motors.

Controls voltage level applied to the azimuth drive motors. In the off position, the motors cannot be driven by any means.

Momentary switches that apply power $(0,12$, or $24 \mathrm{~V})$ to the azimuth drive motors for slewing the dish.

\section{A.3 KEMOTH CONTROL PANRL (Fig. 3 3)}

FLOW RATE

RECEIVER TEMP

PREHEATER
A digital panel meter that reads feedwater flow rate in GPM directly. This meter is actually a tachometer that reads pulses from a magnetic pickup generated by a gear fixer to the feedpump shaft.

A digital panel meter reading temperature $\left({ }^{\circ} \mathrm{F}\right)$ of a type-K thermocouple. The thermocouple can be located in the receiver. A reading yleater than $1100^{\circ} \mathrm{F}$ will cause the dish to slew to the stow position.

In the automatic mode (center switch up), this device controls the temperature at the outlet of the preheater. Desired temperature is set with the round knob and the vertical scale. In the manual position (center switch down), the fraction of full power applied to the preheater (as indicated by the horizontal scale) can be increased (+ button) or decreased (- button). 
THROTTLE, FEEDPUMP, COOLING PUMP

FLOWMETER

SYSTEM

ELEVATION

AZIMUTH

STOW
Remote control of the equivalent control on the flow control panel.

In the BYPASS position, this switch diverts all flow around the turbine flow meter. In the INLINE position, all flow passes through the turbine flow meter.

In the OFF position, the remote control panel is inoperative-all control is via the flow control panel. In the ON position, all control is via the remote control panel.

With the TRACKING switch in the MANUAL mode, this switch is used to drive the elevation motors in either direction at slow speed (12 V) or fast speed (24 V).

With the TRACKING switch in the MANUAL mode, this switch is used to drive the azimuth motors in either direction at slow speed $(12 \mathrm{~V})$ or fast speed (24 V).

Pushing this button forces the dish to stow (optical axis vertical). 
SERT

A-4 


\section{APPENDIX B \\ THERMAL TEST LOOP-COMPONENT DESCRIPTION}

Feedpump

Feedpump Motor

Feedpump

Gearbox

Feedpump

Tachometer

Check Valve

Bypass Valve

Electric

Preheater

Preheater Power

Supply and

Controller

Condenser

Condenser

Cooling Pump

Cooling Tower

Target Meter

Pressure Gauge

Throttle
Giant Model PB-42K, 3-piston positive displacement. Maximum operating conditions: 1725 RPM at 2000 psi, 1440 RPM at 2200 psi, approximately $4.5 \mathrm{GPM}$ at $1725 \mathrm{RPM}$.

Dayton Model 2Z881, DC Permanent Magnet, 1.5 HP at 2500 RPM, 37.8 in lbs. Variable Speed Control: 240 VAC input, 0-180 VDC output.

Dayton 4Z074, Input 2 HP maximum, ratio $5: 1$, output torque 332 in lbs., 345 RPM.

Airpax Series 77 Tachometer 077-432-3110, 262 ms. gate; Airpax 4-0001 Zero-velocity pickup, splitgear, 60 teeth.

Pneu-trol no. 20, 1/4" pipe, $C_{v}=0.54$.

Paraplate no. BR5-3, 1500-3000 psi.

Built by Colorado School of Mines Research Institute. Designed by $M$. Bohn. Total heated flow length is 72 inches. Heating via 48 electrical clamp heaters, each is $1-1 / 2^{n}$ long, $250 \mathrm{~W}$ at $240 \mathrm{~V}$ input, $750^{\circ} \mathrm{F}$ maximum. See Fig. B-1.

Leeds and Northrup \#LN1-2470-AD, $240 \mathrm{~V}, 70$ amp, phaseangle fired, SCR power supply. Leeds and Northrup \#4401-20-33-61-A012-10 Centry Controller, J Thermocouple input, 4-20 mA output.

Built by Colorado School of Mines Research Institute. Designed by $P$. Bergeron and $M$. Bohn. Flow length $=16 \mathrm{ft}$, $3 / 8$ " od tube in 1 " id shell. See Fig. B-2.

Paco no. 105. $230 \mathrm{~V}, 3$ phase, $1 \mathrm{HP}, 8 \mathrm{GPM}, 92 \mathrm{ft}$ total head.

Marley $4705,8 \mathrm{GPM}$ capacity at $125^{\circ} \mathrm{F}$ inlet to $80^{\circ} \mathrm{F}$ outlet at $65^{\circ} \mathrm{F}$ wet bulb.

Ram apo V-1/2-Jo2, SN-6640. Transmitter SGA-835OR, 110 GPM. Output is $1 \mathrm{~V}$ per GPM.

Stedigage, no. 183, 4000 psi, liquid filled.

Whitey SS3IRS4, $C_{y}=0.0$ to 0.04 , ten turns, approxim ately linear from 3 to 9 turns. 

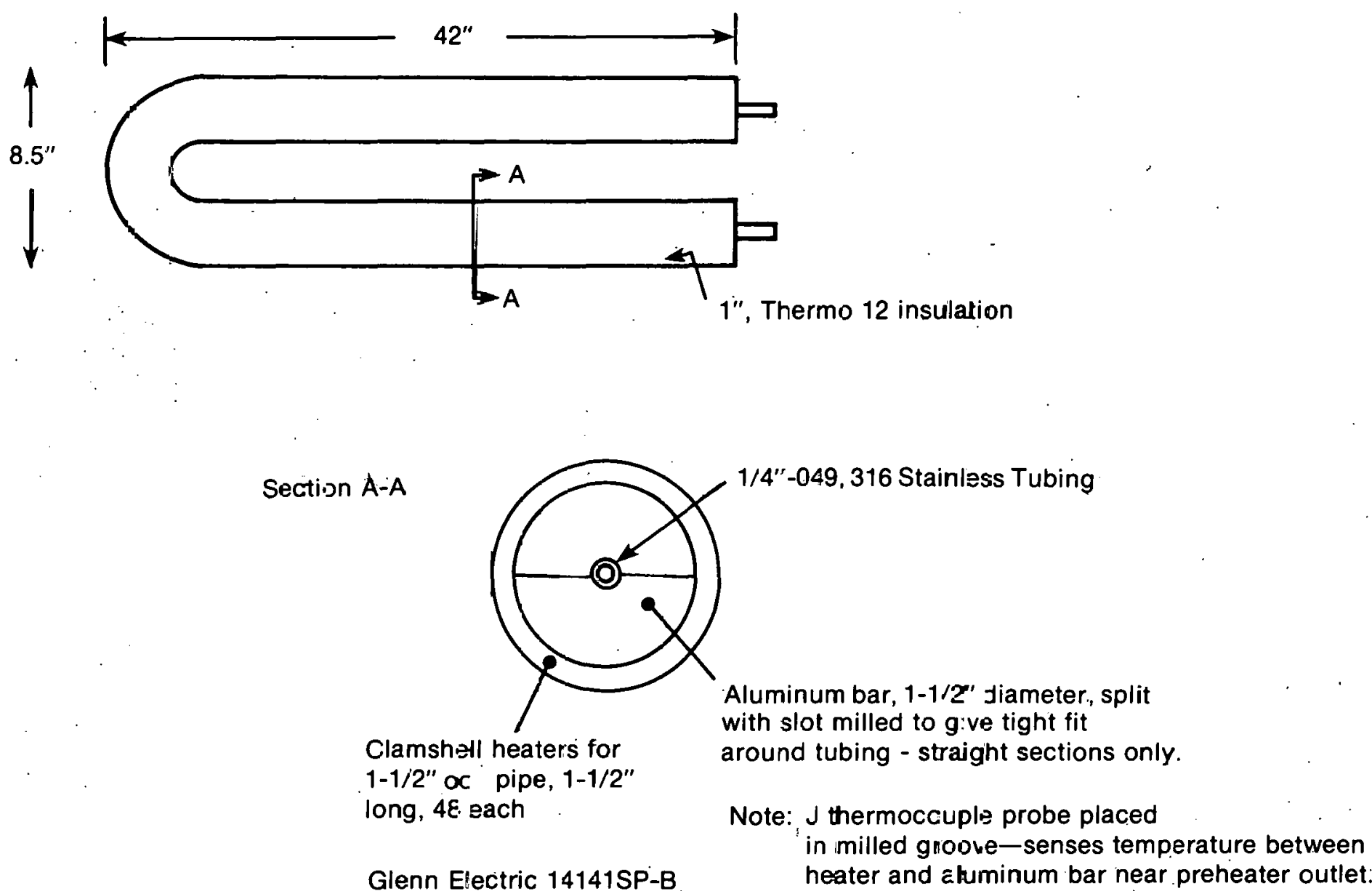

Figure B-1. Electric Preheater. 


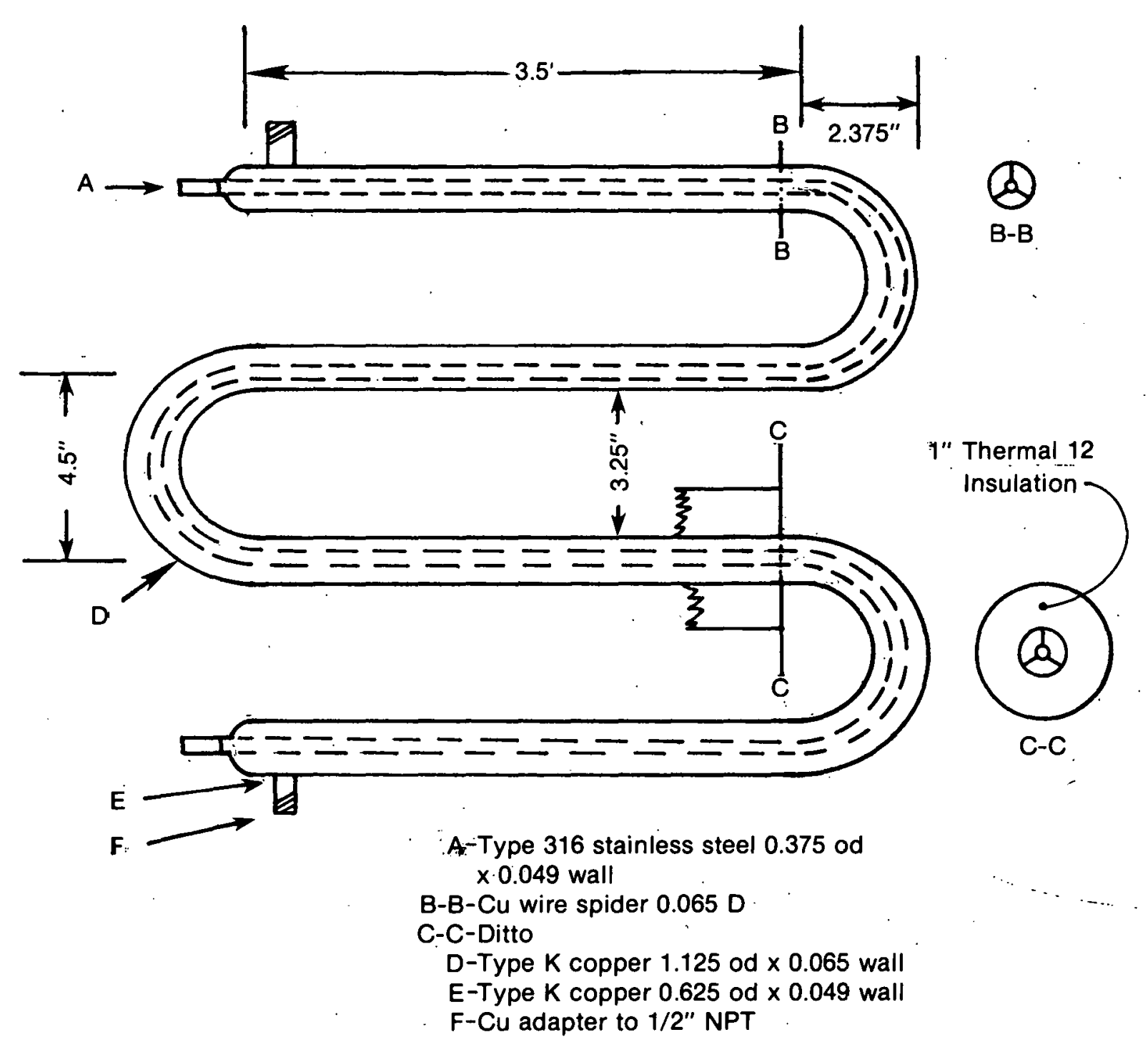

Figure B-2. Condenser 
Throttle Bypass

Throttle

Actuator

Relief Valve

Filter

Filter Bypass

Filter Flow
Whitey SS1 2NBS8, $\mathrm{C}_{\mathrm{v}}=\mathbf{2 . 2}$ wide open.

Montek A3-WR 1092-AD-IND, $110 \mathrm{~V}$ power, 4-20 m A signal, cew on increasing current.

Nupro SS-4CPA2-150, 150 psi cracking pressure.

Nupro SS-4F-T7-230, 250 micron cartridge.

See Throttle Bypass (above).

Whitey SS-IGS4, Toggle type. 


\begin{tabular}{|c|c|c|}
\hline $\begin{array}{l}\text { Document Control } \\
\text { Page }\end{array}$ & $\begin{array}{r}\text { 1. SERI Report No. } \\
\text { TR-637-505 }\end{array}$ & 3. Recipient's Accession No: \\
\hline \multirow{2}{*}{\multicolumn{2}{|c|}{$\begin{array}{l}\text { 4. Title and Subtitle } \\
\text { Advanced Component Research Facility } \\
\text { (ACRES) }\end{array}$}} & $\begin{array}{r}\text { 5. Publication Date } \\
\text { July } 1980\end{array}$ \\
\hline & & 6. \\
\hline \multicolumn{2}{|l|}{ 7. Author(s) } & 8. Performing Organization Rept. No. \\
\hline \multirow{2}{*}{\multicolumn{2}{|c|}{$\begin{array}{l}\text { 9. Periorming Organization Name and Address } \\
\text { Solar Energy Research Institute } \\
1617 \text { Cole Blvd. } \\
\text { Golden, Colo. } 80401\end{array}$}} & $\begin{array}{l}\text { 10. Project Task/Work Unit No. } \\
\text { Task \#3457.12 }\end{array}$ \\
\hline & & $\begin{array}{l}\text { 11. Contract (C) or Grant (G) No. } \\
\text { (C) } \\
\text { (G) }\end{array}$ \\
\hline \multirow{2}{*}{\multicolumn{2}{|c|}{ 12. Sponsoring Organization Name and Address- }} & $\begin{array}{l}\text { 13. Type of Report \& Period Covered } \\
\text { Technical Report }\end{array}$ \\
\hline & & 14. \\
\hline \multicolumn{3}{|l|}{ 15. Supplementary Notes } \\
\hline \multirow{3}{*}{\multicolumn{3}{|c|}{$\begin{array}{l}\text { 16. Abstract (Limit: } 200 \text { words) } \\
\text { A detailed description of the SERI Advanced Component Research Facility (ACRES) } \\
\text { is given. Background information explicates the facility's history, developed } \\
\text { around the two. Omnium-G parabolic dish concentrators. The Omnium-G concentrators } \\
\text { and electrical power plant are described. The purpose and a detailed description } \\
\text { of ACRES is also given. Included is a description of the measurement capabilities, } \\
\text { the controls, and each component of the facility. }\end{array}$}} \\
\hline & & \\
\hline & & \\
\hline \multicolumn{3}{|c|}{$\begin{array}{l}\text { a. Descriptors Solar Collectors ; Solar Receivers ; Parabolic Dish Collectors ; Components } \\
\text {; Research ; Point-Focus Collectors ; Control Equipment ; Measuring Instruments }\end{array}$} \\
\hline \multicolumn{3}{|c|}{ b. Identifiers/Open-Ended Terms Omnium-G Receiver. : ACRES } \\
\hline \multicolumn{3}{|l|}{62} \\
\hline \multirow{2}{*}{\multicolumn{2}{|c|}{$\begin{array}{l}\text { NTIS, U.S. Dept. of Commerce } \\
5285 \text { Port Royal Road } \\
\text { Spriny rield, Va. 2216] }\end{array}$}} & $\begin{array}{l}\text { 19. No. of Pages } \\
39\end{array}$ \\
\hline & & $\begin{array}{r}\text { 20. Price } \\
\\
\$ 4.50\end{array}$ \\
\hline
\end{tabular}

